\title{
IF BAD MONEY IS A COLLECTIVE BAD, ISN'T GOOD MONEY A COLLECTIVE GOOD? ${ }^{1}$
}

\author{
$J_{A C K}$ BIRNER $^{2}$
}

\begin{abstract}
During the current crisis we have discovered that a sick monetary and financial system and bad money are a collective bad. But if that is the case, then is it not reasonable to consider a sound monetary and financial system and good money to be a collective good? One of the reasons economists have not taken up this simple idea is that they have treated money as too homogenous a phenomenon - apart from the fact that economics has never been able to satisfactorily explain why money exists at all. In addition, the great majority of economists were unprepared for the world financial crisis and for the crisis of the euro because they have neglected three basic lessons of economics. By distinguishing different levels of interaction between economic and political agents, I will show that the idea of money as a private good (excludable and rival) with positive and negative externalities cannot fully account for either the positive or the negative effects of money. The concept of money as a collective good (non excludable and non rival) also has its defects. Money as a club good (excludable and non rival) comes closer to accounting for its peculiarities. But the global character of money leads me to conclude that it is better analyzed as a common pool good (non excludable and non rival), at least at the level at which attempts are undertaken to stabilize the world monetary and
\end{abstract}

1 I thank Elisabetta de Antoni for her comments, criticisms, suggestions and improvements and Antonio Chiesi for his help in finding sociological literature. I also gratefully acknowledge the criticisms and suggestions of two anonymous referees. As the author I assume full responsibility for any mistakes. To the extent that the text refers to empirical developments, it reflects the situation of late 2011 - early 2012. At the time of the last revision of the text, the only two significant changes to have taken place since are the stop to the proliferation of European and global agencies expected to remedy the monetary and financial problems, and the announcement by the BCE's governor, at the end of the first week of September 2012, that it would buy, in the secondary market, government debt of countries that asked for help and were willing to commit themselves to implementing structural changes in their public finance and national economies. Draghi has made himself the teacher of the lesson referred to in the closing sentence of this article.

2 Jack Birner is professor at the University of Trento and at University College Maastricht; e-mail: jack.birner@unitn.it 
financial system.

I apply Elinor Ostrom's work on common pool resources to the analysis of money, and in particular of the euro and its vicissitudes. This throws more light on the nature and functions of money, and perhaps even on its existence. There is, however, one crucial difference between the problems of the sustainable natural resources that Ostrom studies and the sustainability of money. Natural resources, if not overused to complete exhaustion, may replenish themselves without human intervention, a process that may be stimulated by an adequate governance system. In the case of social or cultural resources such as money (which is a "social construct"), however, the governance system is part of the resource itself. This leaves intact, but complicates, the relationship between the stock or pool (which in the case of money is trust) that produces a flow of products (monetary and financial services). In order for the stock to be maintained and to continue yielding its services (so: to be a renewable resource), continuous investments are needed. This is a central idea in Friedrich von Hayek's capital theory, which may be used to improve Ostrom's analysis.

So, in order to return to a sound global monetary and financial system, and to save the euro, we should invest in trust. How this can be done is a largely unexplored domain, but I will show that the way European politicians have been acting during the euro crisis is exemplary of how not to solve this problem. Getting the global and the European monetary and financial systems back on track is a complex problem of collective action, which - as Ostrom has shown - is at the centre of the governance of all common pool goods. The story of the euro is a perfect illustration.

KEYWORDs money, public goods, club goods, resources, banking system, crisis

\section{INTRODUCTION}

This essay investigates the implications of a very simple idea. During the crisis that has been plaguing us for the last five years, we have discovered (or rediscovered) that a monetary and financial system that functions badly has effects that nobody can escape: it is a collective bad. But, then, should not a well-functioning financial and monetary system be a collective or public good? ${ }^{3}$ And, by extension, is not money a collective good, either? The answer will be negative, but the road that leads us beyond that conclusion takes us in the direction of the real nature of money in the global context of the crisis. Let me make it clear, though, that my aim is not to find a definition of money; I am interested in understanding money better.

3 The economic literature uses the two terms interchangeably. 


\section{THE FUNCTIONS OF BANKS IN MODERN SOCIETY: A GENERAL FRAMEWORK}

Before elaborating the idea of money as a collective good, I would like to say something about the functions of the banking system and money. What use are banks? What are their functions? The most general way of characterizing the role of banks is to point out that they offer a bridge between today and tomorrow, between the present and the future. The inter-temporal aspect is part and parcel of the monetary and financial sectors. The future is not (fully) foreseeable and is therefore uncertain. In the "real" ${ }^{4}$ economy private and public agents plan their activities, consumption, savings, investments, production processes and sales for the future, something that would be impossible in conditions of total uncertainty.

More specifically, we may distinguish at least the following functions.

1. Money creation. What banks do is to create new forms of money. Every time the Central Bank, the government or an international monetary institution imposes constraints, the banks try to satisfy the demand for liquidity and other financial products by new means. Banks and regulators are involved in a continuous race against one another (in which - and this is important - the regulators are always running behind the banks. $)^{5}$

2. Inter-temporal brokerage. Banks act as intermediaries between those who dispose temporarily of a surplus of money and those who do not have enough of it to realize their plans.

3. This is closely related to the task of bundling, together with the financial system, and putting together the demand and supply of funds.

4. In addition, the banking system acts as an insurance against risks. While a single investor in some productive activity operates in conditions of uncertainty (either the project fails or it succeeds), for a group of investors success of failure becomes a risk that we can attach a certain probability to. This allows us to hedge our bets through an insurance.

As to this last aspect, one of the problems that has emerged during the crisis is that what the financial operators had considered to be risk, really turned out to be irreducible uncertainty. This was also caused by the fact that many of the

4 What is meant are all aspects of an economy where production, consumption and exchange of goods services takes place. I will henceforth drop the quotation marks.

5 Cp. For example, the article that was awarded the Helmut Schmidt prize for journalism in 2011, Katzensteiner \& Papendick 2011, who speak of "ein ungleicher Kampf" - an unequal battle. 
instruments and factors to insure ourselves against particular risks depended on the behaviour of the very same operators and their clients (who also were influenced by innovative products aimed at reducing risk).

The functions of banks mentioned above sustain the functions of money economics traditionally considers: medium of exchange, means of payment, store of value and unit of account. With the possible exception of the last (see further below), all of these need a well-functioning monetary and financial system that guarantees a flow of money that is stable, reliable and predictable. This is closely related to the banking functions' role in providing the necessary conditions for real economic growth. Friedrich von Hayek, who from his earliest publications in economics adopts an inter-temporal framework, ${ }^{6}$ goes beyond this. He says that a partial-reserve banking system compels us to grow - in order to repay the money we have borrowed. Ever since the invention of credit, we have lived permanently above our means. ${ }^{7}$

\section{Competition between banks, supervision and the shadow banking system}

The majority of banks are private enterprises, many of which are quoted on the stock exchange. So, in order to satisfy their share holders banks have to make a profit. If a bank's results remain below those of others, its shares will lose value. This also causes an erosion of its capital, which may make the bank more vulnerable to a take-over. Banks operate in a highly competitive environment; not making enough profit means they are on their way out. In view of the importance investors attach to the return on equity, banks try to make maximum profits with a minimum of capital; this pushes them to increase leverage. Under the pressure of competition banks are practically forced to invent new monetary and financial products with which to attract customers and generate profits. They will move their assets off their balance sheets in order to subtract themselves to supervision or simply because the innovation process leads them to deal in assets that regulators had not foreseen. The fact that in the race between regulators and banks the banks tend to have the lead has created a shadow banking system. It partially has the same functions as the official system but it is not subject to external controls and constraints. The bankers stress that their financial innovations sustain the real economy; the regulators on the contrary perceive many of these innovations as threats to the stability of the monetary system. An example is

6 Cp. Birner 2000.

7 This is illustrated by the situation of Italy. In order to reduce its public debt, it is forced to create the conditions for economic growth, but finds this very hard to realize. Failing to do so would make the amount of public debt (120\% of GDP) unsustainable. 
the recent creation by banks of a system to manage their liquidities outside the existing (and monitored) channels. It is described by Pozsar, who says that "the highly counterparty-intense nature of the "shadow" banking system could be rationalized as an "evolutionary" response to the counterparty diversification needs of ever larger institutional cash pools in a financial system with ever fewer large banks. This search for counterparty diversification occurred through various channels." (Pozsar 2011: 18)

The tension between the function of the banks as inventors of new forms of money and boosters of economic growth on the one hand and the regulators' task to maintain a stable monetary system on the other is clearly described in an article on Basel III in the Financial Times of 3 October 2011:

"As the bankers see it, they are preserving the already shaky world economy and the global financial system. Forcing them to hold more capital and low-yielding liquidity will, they say, make many of their business lines unprofitable and drive up costs for customers. The Institute of International Finance, an industry group, estimates that the reform package could push up borrowing costs by 3.5 per cent, cut global output by 3.2 per cent by 2015 and cost $7.5 \mathrm{~m}$ jobs.

Regulators see it differently. To them, the real threat comes from an unreconstructed industry still addicted to short-term funding that can dry up at the drop of a hat. They also argue that profits remain too dependent on risky derivatives and proprietary trading. Their "impact studies" suggest that enforcing a build-up of capital would trim growth only mildly in the short term. Any pain would be far outweighed over the long run by the benefits of stability."

The comment is in line with Hayek's economic theory, in which the tension between the monetary and real sector has a central part. Our partial-reserve monetary system forces us to grow but at the same time it is inherently unstable. That is because it amplifies every real or monetary shock in a nonlinear way, which creates a discrepancy between prices quoted in money and real relative scarcities. ${ }^{9}$

8 The governor of the Canadian central bank, Mark Carney, who was appointed chairman of the Financial Stability Board in November 2011, has announced his intention to transform the shadow banking system from a threat to the stability of the financial system into a component that shores it up. Cp. "Call to rein in "shadow banking", Financial Times 16 January 2012.

9 See for example, Birner 2000. 


\section{Intermezzo: is money a good?}

So, money is a mixed benefit; it is necessary for economic growth but at the same time carries the seeds of instability within itself. However this may be, money is different from other goods in that, inter alia, it does not directly satisfy our subjective preferences. ${ }^{10}$ You cannot eat, drink or wear money. It is of no use to a Robinson Crusoe. In the environment of a modern developed economy, however, it is indispensable; it is a "second-order good" that stands us in stead to buy other goods. It keeps its nominal value in time and helps us organize production and consumption.

Since money is, in this sense, a "fictitious good" (Polanyi 1944), what the banking and financial sectors produce is - or ought to be - auxiliary to the real economy. For an economy as a whole monetary gain cannot be an objective of its own (that would be a form of mercantilism). A disproportional development of a banking or financial sector, perhaps fed by a money rate of interest below the real interest rate (remember Alan Greenspan's policy in the early 2000s) has, in an inter-temporal perspective (such as Hayek's) created the conditions for the current crisis. The manipulation of the interest rate by monetary and financial authorities made it lose its function as an index of time preference and productivity. As a consequence, it has in the end diverted inter-temporal allocation from its optimum. The handbooks teach us that the financial sector redistributes profits between enterprises and the providers of their capital. If true, financial rates of return, except in the short term, should not be able to be above real rates of return. When this happens anyway, the financial sector is promising more than the real sector can deliver and we are in a situation of financial instability: the excessive promises will sooner or later be falsified.

\section{Economics and the crisis: the Royal Question}

Ever since the crisis exploded in 2008, economics has been the target of many critical attacks. They can be summarized in the question Queen Elizabeth of the United Kingdom asked the economists of the London School of Economics on 5 November 2008: "Why did nobody notice it?"

In order to predict an event, economics, like all other sciences, needs general explanatory theories that describe causal mechanisms and specific initial conditions. One of the ironies of the crisis is that the mechanism that

10 Ingham 2004 rejects the idea that money is a good (which he calls "the commodity theory of money"). I thank a referee for drawing my attention to this book, which deserves more attention than I can give it here. To those who agree with Ingham's position, I can only say that our lack of understanding of money justifies my proceeding, below, on the hypothesis, or fiction, that money is a good. 
started it is explained in every introductory course - economics 101. The progressive fall in value of sub-prime mortgages in the United States ${ }^{11}$ had reduced the value of the banks that had issued them, or bought them as assets. In order to restore their liquidity, the banks were compelled to reduce credits, which in its turn caused a progressive reduction of the reserves of other banks. This is the mechanism of the money multiplier. The only difference with the textbooks was that instead of creating money it was now destroying money. The mechanism is perfectly symmetrical; it was just that almost nobody expected it to go into reverse so massively. Once the reduction in money and credit started to cause a contraction of the real economy, however, the effects were no longer symmetrical. ${ }^{12}$ Through the Keynesian multiplier, which also went into reverse, and the subsequent negative effects on the state of people's confidence, they led to the worrying situation we are now in. ${ }^{13}$

This was only the first economic lesson to be neglected; others that might have helped prevent many of the problems of the euro-area were neglected as well. One is the theory of optimal currency areas (whose presumed ${ }^{14}$ inventor, Robert Mundell, was awarded the Nobel prize in economics for it in 1999): a single currency presupposes a homogeneous real economy. But right from the start of the introduction of the euro it was clear that the member countries were far from homogeneous.

The third lesson, like the first, is part and parcel of any introductory course in macroeconomics. It teaches that there are two instruments of economic policy: fiscal and monetary policy. In case a country is prevented from conducting an independent national monetary policy, all of the burden of interventions comes to rest on fiscal policy. This lesson was ignored with irresponsible lightheartedness when the euro was introduced. The more or less general and implicit idea was apparently that the concentration of monetary policy in the hands of the ECB together with the Treaty of Maastricht would be sufficient for producing a convergence of fiscal policies. ${ }^{15}$ As a matter of fact, all of the

11 Accelerated by derivatives - something I will not go into here.

12 The derivatives created to insure the value of banks' assets that were judged to be riskhomogeneous were often so complex that even their inventors did not fully understand them (cp. Tett 2009). Their role has probably contributed to making the negative process even more asymmetrical.

13 Nouriel Rubini was one of the few economists to combine the relevant causal mechanisms with the relevant initial conditions, but nobody listened to him before the crisis broke out.

14 Exactly the same theory was proposed by Hayek in 1937; cp. Birner 2009.

15 It is significant that all of the countries initially involved cooked their statistics so as to be seen to comply with the Maastricht criteria. 
EMU countries are now compelled to reduce their public debt and deficit, but no one had expected the timing, speed and dimensions imposed by the crisis (and we still have to wait and see if this will be done successfully, or by all member countries).

So, the irony was that part of the reply the economists failed to give to the Royal Question was readily available in the three macroeconomic chapters just mentioned; they were just ignored. Economists had the means to answer the Queen but failed to do so out of neglect.

\section{Economics on money}

But even if economists had been less neglectful of the theoretical resources of their discipline, they would still not have had the wherewithal to give the whole answer. This is because monetary theory shows a gap that economists have not been able to fill despite the efforts of centuries. The public at large, for whom economics is the discipline that studies monetary phenomena, would be understandably surprised to learn that economists have never succeeded in finding a satisfactory reply to what money is, what role it has, or even why it exists. The perfect worlds of economics' most advanced, sophisticated and elegant theory, general equilibrium theory, have no room for money: all individuals have perfect information and can thus exchange goods directly without the use of money. The choice of a unit of value (money) is arbitrary and all money does is to determine the nominal scale or dimensions of an economy. It was only by introducing imperfections that economists were capable of giving an explanation (and only a partial one) of the role of money. The most convincing explanation owes much to Robert Coase; it says that money reduces transaction costs; i.e., everything to do with searching opportunities and information, bargaining and decision processes, and the monitoring and enforcement of contracts. ${ }^{16}$ In this tradition, Robert Clower and Don Patinkin have further elaborated the role that money plays in individuals' decisions to acquire and spend their income. What we have seen during the crisis, however, is that the monetary and financial system has increased transaction costs instead of reducing them. So, what economists would need to do is to discover the conditions under which money reduces or increases transaction costs (find one or more "switch variables"). Such a "conditionalization" would constitute important scientific progress in our discipline.

$16 \mathrm{Cp}$. Niehans 1971, who argues that money in its role as a lubricant is tantamount to serving to reduce transaction costs. 
A tradition in economic thought that has made the negative aspects of the monetary system a corner stone of its analysis is the Austrian School, whose most important representative is Hayek. He explains business cycles as the consequence of the destabilizing effects of the monetary system. Our partialreserve banking system amplifies both real and monetary shocks non-linearly, creating and destroying money through the money multiplier. The economic system is intrinsically unstable and accelerated growth and recessions alternate with one another.

Perhaps the difficulties economics has had - and still has - with money derive from the fact that it has treated money too much as if it were homogeneous. In reality, money means different things to different agents at different levels of interaction. Economic theory has ignored this. A macroeconomic analysis of money is not only useful but it is indispensable - but it is not enough. An exclusively microeconomic approach is not enough either, no matter how necessary the opportunity cost analysis of money is. Money is very heterogeneous. It involves a multitude of relationships and levels:

- individual - individual

- individual - bank

- bank - bank

- bank - national central bank (CB)

- ECB (Fed) - CBs of EMU member countries (federal states)

- national CBs - national governments

- ECB - national EMU state governments

- government - government

- international monetary institutions - national EMU-state governments

$-\mathrm{CB}$ - international monetary institutions, etcetera.

Possibly because they have ignored this heterogeneity, the attempts to integrate money in general equilibrium theory have the same flavor as the epicycles astronomers invoked to save Ptolemy's geocentric model of the universe. Economics needs its own Copernican revolution instead of having to consider the existence of money, the monetary system, its institutions and the way they work as extraneous to economic theory. We have to use different theoretical means. 


\section{WHAT TYPE OF GOOD IS MONEY?}

Economics distinguishes four types of goods according to whether or not they are rivalrous in consumption (the consumption by one individual subtracts the good from consumption by someone else) and whether or not people can be excluded from their consumption. For instance, if I do not pay for a sweater on sale in a shop I have no right to take it away. On the other hand, even if I do not pay taxes, I cannot be excluded from the services of public security. Applying these criteria leads to the following categories:

\begin{tabular}{|c|c|c|}
\hline & excludable & non excludable \\
\hline $\begin{array}{c}\text { rivalrous or } \\
\text { subtractable }\end{array}$ & PRIVATE GOODS & $\begin{array}{c}\text { COMMON POOL GOODS } \\
\text { or RESOURCES } \\
\text { fish stock, clean water, } \\
\text { crude oil }\end{array}$ \\
\hline $\begin{array}{c}\text { non rivalrous/ } \\
\text { subtractable }\end{array}$ & $\begin{array}{c}\text { CLUB GOODS } \\
\text { theater shows, } \\
\text { private parking lots }\end{array}$ & $\begin{array}{c}\text { PUBLIC GOODS } \\
\text { national defence, } \\
\text { lighthouses }\end{array}$ \\
\hline
\end{tabular}

Granted that money is a good, I will now investigate to which category or categories it belongs.

\section{Money as a private good}

The economic theories that I have mentioned above give no explicit answer to the question what type of good money is. According to what is probably the most influential and up-to-date economics textbook in the world, banks, except for central banks, are profit making organizations (P.A. Samuelson et.al., Economics, $19^{\text {th }}$ ed., ch. 25). From here to the conclusion that money is a private good (so, rivalrous and excludable) is only a short step. In fact, it seems as if economists accept this conclusion implicitly. It has not, however, escaped the profession's attention that money creates so-called network effects: money that is accepted by more and more individuals progressively reduces transaction costs. ${ }^{17}$ These effects can be explained as positive externalities of the actions of individual (private) banks. ${ }^{18}$

17 This is practically the only valid economic argument that has been advanced for the common currency. For a critical account by someone who as executive director of the Dutch Central Bank has been closely involved in the creation of the euro, cp. Szász 1999.

18 The existence of such externalities might be used as a justification of the high bonuses of bankers. 


\section{Money as a private good with externalities}

This approach would explain "bad money" in terms of negative externalities. But then, pace Coase ("The problem of social cost"), it should be possible that the individuals who have suffered damages be compensated through the market mechanism by the banks that have inflicted them. This raises the problem of causality. If the negative and positive effects of the banks' actions were only externalities, there would have to be the possibility to internalize them through compensating those who undergo their damages (or exact a payment from those who benefit from its advantages). Such compensations presuppose the possibility to impute ${ }^{19}$ without residue the damages or the advantages to whoever created them. But here the idea that we are dealing with externalities starts to limp: it is not the individual banks that create money, but the banking system as a whole. The modern banking system is characterized by the fact that its effects, both positive and negative, cannot be fully attributed to the actions of single commercial or central banks or governments: between individual causes and collective effects stands the money multiplier. If my bank fails to grant a credit it has promised me, I can take it to court. But someone else, who does not receive a credit from his bank as a consequence of my bank's failure to grant me a credit, what can he do? Take the money multiplier to court? The money multiplier is a systemic phenomenon. If one wanted to talk about it in terms of who is responsible for its working or who is its owner, one would have to invoke some sort of collective responsibility or ownership. In brief: how can you force whoever is responsible for something to appear before a court of law if that something is "nobody's property" (and therefore "everybody's property")? Money and its effects are not simple positive or negative externalities of the actions of individual private banks and cannot therefore be analyzed as phenomena that are inherent to a private good. But if the monetary system and its product, money, cause externalities that cannot be internalized, we are apparently dealing with a collective good.

\section{Money as a collective good}

The title mentions good money as a collective good as opposed to the collective bad of bad money. If taken literally in the sense of the table above, this would mean that money is a non-rivalrous and non-excludable good. I will discuss this below. In the introduction I have also mentioned that a poorly-

19 The problem is very similar to that of the imputation of the value of the final product to the value of the production factors that went into it in joint-production processes. As we will see below, the parallels with capital theory do not stop here. 
functioning monetary system is a collective bad. I claim no copy-right for this. As early as 1999 Mario Draghi, talking about the Asian crisis, launched a very similar idea:

"In today's world of global capital markets and real-time finance, financial stability has emerged as a crucially important public good for the international community."(Draghi 1999: 37)

Put in these terms, financial stability qualifies as a public or collective good according to the usual economic criteria. All agents can benefit from it - provided they respect certain rules - while the benefits of greater stability to one agent do not diminish those enjoyed by others. Not only that, but stability is the exact opposite of rivalrous: one agent's stability increases the stability for other agents with all its positive effects. Moreover - always provided everybody sticks to the rules - no one can be excluded from the beneficial effects of financial stability. ${ }^{20}$ But instead of elaborating this, ${ }^{21}$ Draghi, twelve years later, returns to the concept of externalities:

"[W]idespread is the conviction that the biggest banks cannot go bankrupt. This engenders a series of distortions of competition but above all the unacceptable fact that the gains go to private people and institutions, the losses are born by the collective." (Draghi 2011: 6, my it. and tr.).

The former governor of the Italian central bank, now governor of the ECB, suggests that these externalities only emerge in the case of big banks during crises. He proceeds:

"The SIFI [systemically important financial institutions] must be allowed to fail, if necessary: in an orderly way. Keeping alive the essential functions of banks and the system of payments, so that the cost of their unravelling is not born by the tax payers, but by share holders and some categories of creditors. Starting with the banks of global size and character, they must moreover have a major capacity to absorb the losses. First-quality capital (common equity) remains essential to realize this objective." (ibid., my tr.)

I doubt whether this perspective - which implicitly limits itself to the idea of banks as private enterprises that create externalities - is sufficient for resolving the problems that have given rise to, and continue to worsen,

20 As one referee rightly observes, money as a unit of account is a collective good because everybody can use it and there is no rivalry in its use.

21 Neither does Popescu 2009, one of the few articles that speaks of money as a collective good. 
the crisis. On the one hand it is true that even a well-functioning banking system, by its nature, always risks illiquidity (something Draghi does not talk about) and insolvability (the problem he addresses). On the other hand, it remains difficult to conceive of money - whether or not it fulfils its role well - as a private good with positive or negative externalities if these are not compensable by whoever is their source. It is the malfunctioning of the monetary system as such that has caused the negative effects that we are suffering from. As far as I know, however, nobody has drawn the logical conclusion that if bad money ${ }^{22}$ is a collective bad, then good money ${ }^{23}$ must previously have been, and, one hopes, will become again, a collective good.

In the above I have already observed that, probably because money is dispensed by private banks, economists seem to have drawn the implicit conclusion that money is a private good. But nothing keeps private organizations from providing collective goods (just as private goods may be provided by public institutions - as happens very often ${ }^{24}$ ). So, in the case of money the crucial question is not who provides it but what characteristics it has, those of a private good or a public good. The scheme above shows that in economics the usual distinction is whether or not a good is rivalrous and excludable. In the case of a public good, no one can be excluded from its services and the fact that some benefit from it does not limit the possibility of others' benefiting from it. No ship can be excluded from the services of a lighthouse and the fact that it guides the Queen Elizabeth (the ship of the Cunard Line) does not detract from the use I can make of it in my little sailboat. ${ }^{25}$

\section{Money as an excludable good}

According to the criteria just mentioned, money would not qualify as a public good. Let us, for the moment, limit ourselves to non-excludability. Only someone who gives something in exchange, who sacrifices something, can (legally) enter into the possession of money. In other words, whoever does not

22 "Moneazza" in the dialect of the city that has contributed to many a monetary innovation, Venice; cp. Boerio 1829.

23 Or "moneona", cp. ibid. The same passage gives as meanings of "monetario": forger, producer of counterfeit money. The fact that this is found in the dictionary of the dialect of the city that has so much contributed to monetary innovations should perhaps be food for monetary economists.

24 Cp. for example Samson 2007, who speaks of "collective public goods."

25 Of course this is true of traditional lighthouses. With the modern electronic devices, it would be easy to exclude someone who has not paid from the services of the gps equivalent of a lighthouse. Remains the fact that who is "lost at sea" for whatever reason is a potential danger to others. 
"buy" a sum of money is excluded from its use. But here we have to distinguish between various levels. At the level of the relationships between individuals money is excludable in the sense described above: if I do not do my work, I will not receive a salary from my employer and hence will not enter in the possession of money. But already at the level of the relationships between individuals and banks things start to be a bit different. Whereas at this level, too, there exists a mutual agreement, my part of the bargain is different. An employer pays me on the basis of a labour contract after I have delivered my labour. In the case of a "payment" of a loan by the bank, the situation is the reverse: the bank gives me the money right away, but my part of the deal, my "performance", lies in the future. Right now, the bank accepts my promise to repay the loan, asking for interest, which is something I cannot ask of my employer to whom I advance my labour services. Another way of stating the difference is that in the case of a labour contract the worker has to trust who pays him whereas with a loan contract it is the bank who has to trust the other party.

So far I have discussed contracts between individual agents. But with the introduction of money a kind of collective contract (or responsibility) comes into play. Georg Simmel puts it as follows:

"Indem der Naturaltausch durch den Geldtausch ersetzt wird, tritt zwischen den beiden Parteien eine dritte Instanz: die soziale Gesamtheit, die für das Geld einen entsprechende Realwert zur Verfügung stelt." (Simmel 1989 [1900]: 213) [6 $^{26}$

The collectivity guarantees the value of the second-order good that money is: a means of payment. When, at the end of the month, my employer pays me, he has fulfilled his part of the contract with me, but at that moment another contract is activated, so to speak. It is an implicit contract with which society, and more specifically, the banking and financial system, takes it upon itself to guarantee that the value in goods and services of my salary will be respected:

"was für den Einzelnen Lösung ist [die Bezahlung], [kann] für die Gesamtheit Bindung sein ... Die Solvierung jeder privaten Verbindlichkeit durch Geld bedeutet eben, dass jetzt die Gesamtheit diese Verpflichtung gegen den Berechtigten übernimmt." (Simmel 1989 [1900]: 214$)^{27}$

26 As barter is replaced by monetary exchange, a third instance interposes itself between both parties: the social collective, that makes available an appropriate real value in the place of money. (my translation)

27 What for the individual is an absolution [payment], [may] be an obligation for the collectivity ... The dissolution of any private commitment by means of money means that now the collectivity takes over this obligation vis-à-vis the rightholder. (my tr.). 
Simmel draws attention to the fact that - following my declaration to my employer that I have nothing further to expect from him - his debt to me is transferred to the collectivity. Whoever enters in the possession of money cannot be excluded from this guarantee or protection. ${ }^{28}$

\section{Money as a club good}

If this is so, then money is a club good (i.e., excludable but not rivalrous): by offering my labour, for which I am paid in money, I have bought the entrance ticket to the community of users of a particular currency whose value is guaranteed by the society that issues it. It is the same with a credit: whoever accepts a credit becomes a "subscriber" to the services for protecting its value that are offered by the institutional framework of the society in question and hence benefits from the advantages of a club good. This is what proponents of a free-banking system lay the emphasis on: individuals are free to choose which monetary club or clubs they want to belong to. ${ }^{29}$

A choice that in modern society is practically excluded is the option of not being a member of any "currency club". Given the wide diffusion of the market system and governments that impose taxes for financing their expenses, practically no one can afford "not to be a member". ${ }^{30}$ Modern economic life is so thoroughly monetized that in most cases one could not even exchange one's labour or other resources directly against others if he wanted to: all of us are practically compelled to be member of "the money club". The other side of the medal is that no one can, as a matter of fact, be excluded from the use of money. The club that I am a member of is very big and it leaves me with little choice to leave it. For the euro it coincides not only with Italian society (remember that before the euro the Italian central bank had the monopoly of emission of money) but the whole euro area (where the exclusive right or monopoly of emission is in the hands of the ECB). Now, if the coverage of the "money clubs" is so vast and dense, no one can, as a matter of fact, exclude himself from membership of his own accord or be excluded.

28 Until not too long ago, the banknotes of European countries contained a phrase similar to that on English banknotes, "I promise to pay the bearer on demand the sum of .... Pounds", with the signature of the head cashier of the Bank of England. Euro bank notes no longer carry this statement.

29 The same holds for the choice between national currencies.

30 The colonization of the last centuries has been an important forced contribution to the diffusion of the money-based economy. 


\section{Money as a common pool good}

There are other problems with the idea of money as a club good. At the level of relationships between individuals, the money I have in my pocket cannot at the same time be in somebody else's pocket. But then money is not only not an excludable good but it would also be subject to rivalry in use (be subtractable). But then it would not be a club good. So what type of good is it? The analysis of goods that are both rivalrous and non-excludable is the focus of the work of 2009 Nobel prize laureate Elinor Ostrom. Goods of this kind are called common pool goods (or resources, CPRs).

Another problem with the concept of money as a club good is that at the global level of relationships between countries there are various "currency clubs" whose central banks hold substantial reserves in other countries' currencies. At the end of April 2011 the Chinese central bank held reserves in American dollars for a value of $\$ 3$ trillion (three thousand billion). The same goes, be it in minor but still substantial amounts, for Chinese reserves in other currencies, for the Fed, the ECB and the central banks of the emerging economies (as they were known as until recently). Now when a particular monetary club is an important "shareholder" of others and vice versa, it is in the interest of all of them that these currencies be managed responsibly and predictably: major fluctuations in their domestic value would have inflationary or deflationary effects and influence their balance of payments. Hence, at the global level of the relationships between central banks there is a problem of collective action, which is an additional argument for thinking of money in terms of common pool good in the tradition of Ostrom.

So, private banks, which together and together with central banks create money, are providers of a particular type of common pool good. This conclusion would make it necessary to revise and reconstruct our way of thinking of the monetary system. Using, inter alia, Elinor Ostrom's ideas, I will apply the theories or models of collective property outside its original domain. So part of the question becomes: what can we learn from Ostrom's approach if we apply it to the global monetary and financial system? We will discover, in Ostrom's spirit, that we stand to gain insights not only from economics but also from law, sociology and other disciplines, all of which contain parts of the solution to the puzzle. We will find ourselves quite a bit outside the traditional domain of monetary analysis, indeed! 


\section{HOW TO PROCEED?}

As a first justification of this somewhat hazardous step, let me remind you of the failure of theoretical economics to come to grips with money even when it functions well. But how to proceed? Following in Ostrom's footsteps, we might make a catalogue of actually existing local monetary systems that are the outcome of more or less spontaneous efforts to organize them. Cooperative banks seem a promising category to start with. One of the problems of the phenomenon I address, however, is that it is part of a global system: all monetary systems, except perhaps for the most primitive ones, are part of it. What happens in the world of cooperative banks is not separated from developments in the rest of the global monetary and financial system. An alternative approach would be to look into the history of monetary systems. That would certainly be a worthwhile undertaking but it will have to wait. Yet another path of research that we might follow and which is part of the Ostrom tradition is the experimental one.

We need not go far in order to find all three analytical approaches combined together in reality: as of 1998, we are part of a one-to-one scale laboratory experiment with a monetary system whose history is recent and welldocumented: the euro. Therefore, from now on, I will concentrate on the euro, borrowing some of Ostrom's ideas (in the hope of paying them back with interest - which at the current rates might not be too difficult...). I will frequently refer to articles from newspapers such as the Financial Times. This is not for lack of intellectual depth, but reflects the almost complete sense of disorientation on the part of economists: almost none of them foresaw the crisis and nobody knows how to deal with it. Nobel prize winners such as Stiglitz and Krugman have published books on the crisis but buying them only serves to understand how rapidly they have changed and continue to change their ideas. ${ }^{31}$

\section{Money as a common pool good and the problem of collective action}

The domain of money is one in which problems of collective action abound. This is already clear at the level of the relationships between banks and their customers. As long as a bank has a good reputation and is trusted by its customers, there are no problems. But as soon as rumors spread that the bank can no longer honor its obligations, what happens? Customers who know

31 This passage should not be read as a total rejection of an economic analysis of money. On the contrary; both macroeconomics and microeconomics are indispensable for understanding money. But they are not enough. 
how our monetary system works might try to convince others to leave their deposits in the bank. But who can guarantee that if I leave my money in the bank, others will do the same? This is a typical prisoners' dilemma situation, an instance of a collective-action problem. So, what do I do? Better salvage my money, so I withdraw my deposit. But I am not the only one to follow the same reasoning; all customers do so. This is the dominant strategy, which causes a run on the bank and the expectation that the bank is illiquid becomes self fulfilling: the bank does not keep all of its assets in the form of liquidities and cannot pay back all of its account holders - even if it is not insolvent. We will see other examples of collective-action problems in monetary situations, but this one indicates that we are on ground that has been investigated by the Ostrom tradition.

This is strengthened by the fact that, according to Ostrom et.al. (1992: 158), "[g]oods that are subtractable in nature are better defined as commonpool resources." That things may not be so straightforward, however, may be concluded from next sentence:

"Social dilemmas related to CPRs share with public good provision the problems of free riding, but they also include the problems of overharvesting and crowding. ... In a CPR environment, an increase in the number of participants, holding other variables constant, is negatively related to achieving social benefits." (ibid.)

The possible negative effects of an increase in the number of agents seem contrary to the network effects that are attributed to money. This appears to throw doubt on the concept of money as a common pool good. In order to investigate how fruitful that idea really is, we have to look more closely at Ostrom's analysis.

Ostrom 2010 identifies the following structural variables as determinants of the probability that successful collective action will be undertaken:

1. The number of participants or agents involved. According to Mancur Olson there is an inverse relationship between the size of the group and the likelihood that it succeeds in creating or maintaining a public good. That is because the higher the number of agents, the less visible will be his contributions, and the higher will be transaction costs.

The repeated and frequent attempts to save the euro are clear examples that we are dealing with problems of collective action. They show many of the features that characterize collective action: moral hazard, the fear that not all countries will contribute to sustaining countries in trouble (free riding), and others that will be discussed below. Already before the euro area came 
to include more members it was evident that the governance problems would have increased with the access of new members.

2. On the other hand, when a group enjoys the benefits of joint supply of a resource, group size has a positive effect on the probability that it will be provided. But the number of participants may also have negative effects for the following reasons: "Social dilemmas related to CPRs share with public good provision the problems of free riding, but they also include the problems of overharvesting and crowding. In a CPR environment, an increase in the number of participants, holding other variables constant, is negatively related to achieving social benefits." (Ostrom 2010: 158)

And indeed, the case of the euro offers a mixed picture. When the common currency was being launched, there was a general sense of optimism in which the euro was apparently thought of as a public good: joint supply and the expectation of a series of economic advantages (amongst which network effects) that should have been the contrary of the effects of subtractabilty. As it turned out, though, countries with low standards of fiscal discipline behaved as free riders, financing their public and private debt with low-interest loans. Thus, the fiscal position of the weaker countries has made it more difficult for the stronger countries to finance their debt (I remind the reader of the threat, in November 2011, carried out a few months later, to lower the rating even of some of the stronger countries). So now the easy access to financial markets that weaker countries enjoyed in the past is limiting the possibilities of stronger countries to finance their debt, thus transforming the euro from a currency with the characteristics of a collective good into one that is more similar to a common pool good.

\section{The heterogeneity of participants, often indicated as a deterrent to} cooperation.

One form of heterogeneity is asymmetry. At the level of the relationships between individuals and banks, if you have a small debt with the bank, it is your problem; if you have a big debt with the bank, it is the bank's problem. This is a simple truth that not only applies to individuals but also to the relationships between the ECB and the EU countries. If the ECB buys large quantities of sovereign debt, it makes itself dependent on the fiscal policies of the issuing countries and in this sense loses its autonomy. This is the domain of asymmetric games. During the crisis we have discovered that the debt problem (public and private) was so vast as to constitute a danger to the banks, the public at large and to governments. The problem of banks and countries that are too big to fail is in part a question of their financial weight. 
In part it is related to their position and degree of connectivity within the system (see 6 below).

In the case of certain countries, an external solution to the too big to fail problem is excluded by the fact that they are also too big to save. Greece with its small dimensions could be saved but Italy's and Spain's public debts exceed the "fire power" of all European financial institutions put together. In addition, a "sovereign bankruptcy" of Greece would not seriously menace the future of the euro - provided the risk of contagion could be contained. If, on the contrary, Italy or Spain ceased to honor their public debt, the financial collapse of either would probably drag down the whole euro system with it.

As to homogeneity, if the member countries of the common currency had been part of an optimal currency area, the problems would certainly have been less or even totally absent. As it was, however, the governments of all member countries, from Germany to Greece, have been capable of financing their public debt, until recently, at the same interest rate independently from their very different growth prospects, labour costs, competitiveness and fiscal discipline. On the one hand this illustrates that we are dealing with a host of collective-action problems, such as moral hazard and free ridership; on the other hand it shows that even the most virtuous countries have not opposed, when there was still time to do so effectively, these behaviors because the common currency was in their interest, too. This is particularly clear in the case of Germany, that thanks to the common currency was able to sell its products abroad at prices below what they would have been had the Deutsche Mark still existed. ${ }^{32}$ Every country stood to gain something, with advantages varying from country to country. In order not to lose its own specific advantages the government of each country closed an eye when it came to criticizing the effects of the pursuit of the advantages by others, even though it should have been perfectly clear that these advantages, and particularly the lack of fiscal discipline, would have put the entire euro project in peril.

4. Face-to-face communication. The theory of non-cooperative games predicts that the way in which agents communicate with one another leaves the outcome of social dilemmas unchanged, but repeated experiments and other empirical results contradict this. According to Ostrom it is a mystery why this is so.

In the case of the euro crisis it seems perfectly clear that the communication

32 According to estimates by Le Monde of 31 December 2011, German exports to other European countries have increased by $9 \%$ per year since 1998 , against $3 \%$ during the period 1990-1998. 
between heads of European and other governments, governors of central banks, the director of the IMF etc. plays an important role in the attempts to find solutions. Just think of the faces Sarkozy and Merkel pulled and the explosion of laughter that followed during the press conference of 23 October 2011 after a journalist had asked if they trusted the Berlusconi government. Three weeks later, Berlusconi stepped down. What also counts here are power (and hence dependency) relationships. A debt situation always creates a position of inferiority, for individuals as well as countries - except when a big private or public debtor has bargaining power, particularly when the stakes are high, as in the case of the survival of the euro. Greece is a good example. ${ }^{33}$

\section{Information on past actions may make much difference for the choice of} strategy in repeated interactions.

This, too, is clear in the European case, even though virtuous past behavior, even if it is recent, is not sufficient to guarantee trust or the right to have a real say in matters (Ireland). On the other hand, there is a lag when it comes to countries with a less-than-virtuous past that have bettered their ways, such as Italy. ${ }^{34}$

6. How agents are related in a network. According to Ostrom, in a onedirectional network individuals have a higher probability to contribute to the well-being of others than when the individual resources are put into a common pool from which all of them may benefit. In addition, "[c]reating a particular type of network may change the structure of the game from an n-person PD to an Assurance Game (Yamagishi \& Cook, 1993)", ibid.:159).

There is no doubt whatsoever that network structures are of great importance for understanding phenomena such as contagion and the crisis, but this is such a vast and complex field that I prefer not to go into it here. The resources of network sociology would be very useful to make progress here. Let me just repeat what I observed above: the problem of too big to fail is not just a question of the financial weight of an agent but also of his position and connectedness in a network. ${ }^{35}$

33 Instead of continuing to ask for support to remain within the euro area, Greece might have asked for favourable conditions in exchange for leaving it. Until, roughly, the Spring of 2012, this might have given the country a stronger bargaining position.

34 At the moment of the first revision of this text, in early February 2012, it seemed that the Monti government was winning back lost ground. At the time of the last revision, in August 2012, the situation is less clear.

35 Part of Birner 2009a is dedicated to these aspects. 
7. The possibility that agents may enter and leave more or less voluntarily.

The treaties on which the EMU is based do not foresee the possibility of a member's exiting ${ }^{36}$ we are on completely uncharted terrain. But there is nothing as a matter of fact to keep a country like Greece from leaving the common currency group. It might be in its interest to do so as it would allow Greece to improve competitiveness through the inevitable depreciation of the drachma. But the fear of other countries that the exit of one or more members would cause a wave of distrust and sink the euro gives Greece a bargaining power far out of proportion with its economic weight - even though since November 2011 the possibility of a euro area without Greece has been taken more and more seriously.

Putting all this together, I think there are enough parallels between the recent history of the euro and the factors mentioned by Ostrom to make me think I have chosen a promising approach.

\section{Money as a cultural resource}

Common pool goods such as water, a commons, or clean air are resources that exist in nature without human intervention. Money, on the contrary, exists only by virtue of the belief or the conviction of us humans that money has monetary characteristics. This is not a tautology; money in its various forms is accepted as a means of exchange or in any of its other roles not because of any objective characteristics but because we believe that it is capable of fulfilling these tasks. ${ }^{37}$ Physical natural resources exist also without us humans but they can be destroyed by human intervention. Social resources, on the other hand, whether they have been deliberately created or emerged spontaneously, not only can be destroyed by us but also depend on us for their very existence. A natural resource such as water was there before we used it; money, on the contrary, owes its emergence and existence to the ideas and expectations we human beings have and share: money is a cultural artefact.

If the ideas individuals have of the functions of money are not sufficiently congruous, money ceases to have these functions and hence ceases to exist. Sociologists would say that it is a social construction. In this sense money is an institution for whose continuity it is necessary that there exist a "social equilibrium" in the sense that, as I have just observed, the perceptions and expectations of the individuals who use its services are sufficiently

36 Cp. Athanassiou 2009.

37 As the writing on Maltese coins of the past said: "non aes sed fides" - not copper but trust. 
congruous. ${ }^{38}$ To give an example, if nobody sends his cows to graze on the commons, the grass grows back; if, however, agents on either side of a market (demand and supply) lose their trust in a certain currency, it ceases to exist as such (the banknotes and coins would continue to exist as physical objects but would have lost the functions which, in sociological jargon, make up its symbolic value). This applies directly to the euro. If what the Greeks expect of the common currency diverges too much from what, say, the Germans expect of it, the survival of the euro is jeopardized. This is, of course, a very general way of characterizing the problems with which the 17 EMU members are trying to come to terms; one would need to enter into the details in which the various perceptions and expectations express themselves and analyze the monetary and political institutions and mechanisms within the euro area and on a global scale to have clearer ideas of where solutions may be found. It seems obvious, though, that if the economic conditions in the member countries are very heterogeneous, there will be a growing divergence in the perception of how the euro may help to save one's own economy. In these circumstances an appeal to social cohesion is not very likely to keep the EMU together.

So, cultural resources such as money differ from natural resources in that they are founded on people's ideas. What they have in common is that both need investments in order to maintain them. Both natural and social renewable resources are forms of capital in the sense of Austrian economics:

"It is this problem of why the existence of a stock of non-permanent resources enables us to maintain production permanently at a higher level than would be possible without them, which is the peculiar problem connected with what we call capital." (Hayek 1942: 54).

The distinction Hayek makes between stock and flow is identical to the one Ostrom introduces in her analysis of common pool goods. The problem of common pool goods is to find a system of governance that allows the stakeholders in resources - which form a pool or stock - to produce a flow of goods and services without depleting this pool or stock. The problem of the governance of renewable resources in Ostrom's sense is identical to that of realizing the investments that are necessary to maintain a certain desired flow of goods or services. Applied to money, this means that in order to keep up a flow of "good money", it is necessary to invest in the stock of social capital that produces it.

38 Cp. Birner 1999 e Birner \& Ege 1999. 


\section{Money and trust}

By definition the value of fiduciary money is based on the trust we have in the institution that puts it into circulation. ${ }^{39}$ Kenneth Rogoff (Financial Times, 9 August 2011) correctly observes that the current crisis is not a credit crisis but a credibility crisis. The concept of fiduciary money and Rogoff's comment confirm the idea that money is a common pool good: in Ostrom's analysis of common pool goods and the collective-action problems that they create, the main distinction is between a stock or pool of resources on the one hand and the flow of goods and services it produces. Money in its various forms is one of these. So, instead of thinking of money as M, which is a stock, its services should be represented by MV. Now, at a more general and abstract level the stock that produces these monetary and financial services is trust. Of course, trust resides or is crystallized in a more concrete institutional framework: banks, monetary and financial organizations, laws, relationships between various organizations, between monetary and financial organizations and governments, between governments, etc., the whole list of relationships given above.

Trust: a renewable resource?

In their analysis of physical common pool resources Ostrom and Hess look for a solution to collective-action problems in designing an adequate system of property rights:

"Devising property regimes that effectively allow sustainable use of a common-pool resource requires rules that limit access to the resource system and other rules that limit the amount, timing, and technology used to withdraw diverse resource units from the resource system." (Ostrom \& Hess 2007: 10)

It is, however, difficult to see how this sort of solution may be applicable to trust. For instance, in the case of trust the opposite from what the authors say about limiting access seems to be true: in order to resolve the crisis, more trust is needed, not less:

"The central irony of the financial crisis is that while it is caused by too much confidence, too much borrowing and lending, and too much spending, it can only be resolved with more confidence, more borrowing and lending, and more spending. Most policy failures in the US stem from an inability to appreciate this truism and therefore

39 But after centuries of fiat money, is not the relationship the reverse and is not trust based on money and the institutions producing and protecting it? 
steps are taken that would have been productive pre-crisis but are counter-productive now with the economy severely constrained by lack of confidence and demand." (Larry Summers in the Financial Times, 24 October 2011)

The importance of trust for putting the euro and the global monetary system back on the rails is illustrated by the recapitalization of banks. Though judged necessary by regulators, and by the banks themselves, increasing a bank's capital means lowering leverage and hence profitability. Attempts to increase the banks' capital in times when the price of their shares have fallen dramatically (according to the Financial Times of 22 October 2011, the biggest French banks have lost between 45 and $61 \%$ of their value since January 2011) would attract little capital. The value of banks' shares has plummeted because investors have lost confidence in the banks. If they were to regain their confidence, recapitalization would become easier, less costly, and in the end, would increase trust.

The problem is how to convert a negative spiral into a positive one. This is a problem of collective action. For instance, whereas from the solvency point of view it is in the interest of every single bank to increase its capital (and its liquidity), no bank will be the first to take the initiative as this would reduce its competitiveness (issuing more shares means having to pay more dividends and having fewer retained earnings for reinvestment) if the others failed to follow suit. In order to achieve the objective of strengthening the banks' solvability without reducing their relative competitiveness, they would have to accept what the Dutch economist Hans van den Doel has called voluntarily accepted coercion by an external agent. This is a variant of Hobbes' problem. The likelihood that the banks will find a solution to this problem spontaneously is close to zero - also because strengthening bank balance sheets cannot wait. The Basel III proposals illustrate the need for pressure by an external agent which has a certain authority: the banks have already begun to implement - be it very partially - some of these proposals aimed at improving their solvability.

Timing is essential for surveillance and regulation. As Patrick Jenkins observes (Financial Times, 9 August 2011), once certain rules (such as those of Basel III) have been approved, markets cannot wait for them to be implemented. Markets typically anticipate developments on the basis of people's expectations (which may be mistaken). And indeed, the banks have already started strengthening their capital in a limited way. This has reduced their profitability, with the consequence that investors no longer consider bank shares as vary attractive investments (the day before Jenkins' article 
appeared, the shares of big banks had lost - in one session - 23\% - Bank of America, 22\% - Citigroup, and 15\% - Morgan Stanley). Jenkins proposes a "holiday" of a couple of years during which banks are left alone instead of insisting on further rules. His implicit premise is that the lack of interest in bank shares jeopardizes the function of banks as inventors of new forms of money - which threatens to undermine economic growth.

To return to the central problem, viz., whether trust can be renewed, according to Reinhart and Rogoff 2009, the financial and economic systems of afflicted countries have recovered after every crisis of the past, though often after a decade or longer. Apparently, trust is a renewable resource but we do not know the mechanisms that are responsible for this. The discussion above should have made it clear that trust is a, or the, central element of social capital. The lesson of the Austrian School is that capital is a resource that needs continuous investments in order to produce a flow of goods and services. So the question becomes what we have to invest in the stock of trust so that it may renew itself. Here lies a vast and largely unexplored field of research. One would expect sociologists to have dealt with this. Möllering 2006 is an attempt to throw more light on the nature and role of trust. His analysis, however, which is inspired by phenomenology, is very philosophical and would need to be translated into theories that are closer to the empirical reality of money. The core of his analysis is as follows:

"[T]rust is an ongoing process of building on reason, routine and reflexivity, suspending irreducible social vulnerability and uncertainty as if they were favourably resolved, and maintaining thereby a state of favourable expectations towards the actions and intentions of more or less specific others." (Möllering 2006: 111)

Möllering's theory and the quoted passage deserve more comment than I can give here. Let me just make some observations. The quotation seems to apply to situations in which a climate of trust already exists and in which there is an equilibrium between trust, reason, reflexivity (by which the author means a process in which agents learn to trust each other) and routine. Where trust is lacking, however, as is the case of the crisis, this equilibrium breaks down. It seems that there are not even the mechanisms or factors in the sphere of reason, social learning processes (reflexivity) or routine that can compensate the fall in trust. One would have to investigate if such compensation mechanisms exist or if the weight between the factors may shift. The passage quoted from Larry Summers above points in the direction of a need for increasing trust when trust itself and perhaps the other factors are weakened. 
Möllering speaks of trust as an attitude that involves an act of faith, an irreducible component of the nature of man. Putting it like this smacks of essentialism but perhaps the idea can be developed into an empirical hypothesis. One might, for instance, examine if people in conditions of high trust widen their time horizon, i.e., plan for a more remote future. A situation like this would have different economic and financial consequences than a restriction of the time horizon.

\section{The euro and problems of multiple and complex collective action}

The fluctuating behaviour of (former) Greek prime minister Papandreou (on Monday 31 October he announces a referendum on the package of measures to save the country's economy, on Thursday 3 November he stops it) illustrates that the global financial and economic crisis, especially in Europe, is a complex of collective-action problems between a multitude of agents at a variety of levels. Without trying to be complete, we can distinguish the following relationships that are relevant for the euro area:

- national governments - citizens: Greece, Portugal, Spain, Italy, Germany etc. face different problems here;

- government - government: the latest government to undergo pressure from others, and particularly from the two leading countries, Germany and France, is Italy;

- governments - ECB

- governments - EFSF

$-\mathrm{EFSF}-\mathrm{ECB}$

- G20 - rest of world

- banks - banks

- banks - supervisors: the attempts to implement the measures of Basel III are a textbook example of collective-action problems that go right to the core of what we may call the central tension (or paradox?) of money: a common pool good that is produced as if it were a private good, by private enterprises, the banks, that are exposed to market competition;

- rating agencies - banks

- rating agencies - governments

- euro area - rest of Europe

- euro area - rest of world.

All of these agents (in a very general sense of the word) are involved in the attempts to find a solution to the problems of sovereign debt and others. 


\section{The monetary system: whose property?}

It seems problematic for the governance of money to follow Ostrom's idea that we have to design an adequate system of property rights. First of all, Ostrom's approach raises the problem which property regimes would apply, or, in other words, who owns the monetary and financial system? Obviously, the question is more general: who is the owner of social institutions? In certain cases, misbehavior by banks leads to their nationalization and become public or collective property. Theoretically, this would be possible for the whole banking system, but it would reduce competitiveness and hence economic growth. Discarding collective property, we might look at stakeholders instead of owners. Here again we hit upon a theoretical vacuum. Following the example of Mahoney et. al. 2004, who examine the possibility of founding a theory of stakeholdership upon a theory of property rights (in enterprise in their case), we might try to generalize Ostrom's proposal into the question which sorts of stakeholdership regimes offer the perspective of finding forms of governance of the monetary and financial system that reduce the danger of bad money. Going in this direction seems to me to be in the spirit of her work; one might even say that what Ostrom does with her distinction between different property rights is to map the different types of legitimate interest people may have in a common pool good..$^{40}$ The same individual or institution may have one or more of the following rights: access, withdrawal, management, exclusion, alienation.

As far as the EMU is concerned, the 17 member countries have the right of access; other countries may ask for access, but this will not be easily granted in the current conditions. On the right of withdrawal the treaties underlying the common currency remain silent. ${ }^{41}$ The management of the euro is left to the ECB, in which the central banks of all member countries are represented. The right of exclusion is not defined either by the treaties; in practice it could be exercised by refusing to grant further financial aid to countries in difficulties. After Papandreou had menaced by proposing the holding of a surprise referendum on the austerity package, the heads of government of the two strongest euro countries replied with the counter-menace of suspending financial aid to Greece - with an instant result. The right of alienation would apply, at the most, in a very limited manner to the monetary and financial institutions of the euro area. Under current conditions it is difficult to imagine the sale of the ECB or the EFSF, which would amount to their privatization.

40 See for example Ostrom 2003: 249-50 and Poteete et.al. 2010: 95-6.

$41 \mathrm{Cp}$. Athanassiou 2009: 9. 
Two mechanisms for resolving problems of collective action: politics and the market

Economics teaches that there are two mechanisms for aggregating individual preferences, politics and the market. In a political system we vote with a pencil, on the market we vote with our money. Apart from being alternative ways of aggregation, these mechanisms are also alternative solutions to a problem of collective action, which stand a (usually very high) number of individuals instead to decide what the collective preference for certain goods and services will be. The crisis has thrown doubt on the idea that these are alternative collective decision-making mechanisms. It looks rather as if the market has become the "decider of last resort" that has the power to correct politics (and hence, in a democratic system, the results of the aggregation of individual preferences through the voting system). As indicated in the previous paragraph, we were used to governments judging and evaluating markets, often with the purpose of regulating them. The period starting in the Summer months of 2011, however, has presented the almost unprecedented spectacle of markets judging governments. Recent examples are the resignation of the Berlusconi government under the pressure of the threat of exploding yields on Italian government bonds (perhaps the most dramatic example), the Zapatero government for its incapacity to solve Spain's economic problems, the Papandreou government for both reasons in addition to further economic and political problems, preceded by the Cowen government in Ireland and the Sócrates government in Portugal. The painful, hesitating and reluctant struggle of European governments with Greece's debt problem and, on the other side of the Atlantic, the political battle between the White House and the House of Representatives (and mostly with Republicans) over the raising of the limit of American public debt have shown the grown influence of the opinion of markets over politics. Instead of being judged only by the polls, politicians are also judged by private investors' willingness to buy the various countries' public debt, by spreads, rating agencies ${ }^{42}$ and the quotations of credit default swaps.

What reinforces the influence of markets on politics is that the crisis of the American economy occurs at the same time as the crisis of the euro (because they are related): investors look for assets with the most attractive returnto-risk ratio, which causes sudden and massive changes in the direction of

$42 \mathrm{Cp}$. the article by Barker and Wilson in the Financial Times of 16 January 2012, according to which the lowering by Standard and Poor's of the rating of half the euro countries that had just occurred really was a negative verdict on the failure of European politics to solve the euro crisis. 
capital flows. These changes have become very sensitive to the behavior and even the announcements of (groups of) politicians who are perceived as international leaders. The German chancellor Merkel is a good example for the European area and an earlier example for the US is the tea-party movement. In the words of Vince Cable, former English undersecretary of economics and chief economist of Shell Company, "The irony of the situation at the moment . . . is that the biggest threat to the world financial system comes from a few rightwing nutters in the American Congress rather than the eurozone." (quoted by Alan Beattie, "Markets warning over debt. White House and Republicans clash. Two-stage deal urged by Boehner", Financial Times, 25 July 2011).

The crisis compels us to revise more of our accepted ideas, presumed certainties and mechanisms that seemed to have acquired our trust over more than a century. These include the idea that government bonds are the most solid investments possible; ${ }^{43}$ that the financial sector offers the means to invest profits made in the real sector; that one of the tasks of politics is to judge markets and not the other way around; that the monetary sector provides the lubricant to make the real sector function more efficiently and smoothly; and the mechanism in which the central bank is the lender of last resort.

\section{Bipolar and polycentric systems}

As I have observed above, the two systems of aggregation of preferences, political elections and the market, are at the same time solutions to the problem of collective action. In the perspective of the "Bloomington School" of the Ostroms and others this is an example of bipolarity. One of the results of their research is that the choice of the system of governance of common pool goods is not only one between government and market. They have discovered that many "polycentric" governance systems have evolved, each with its own competencies and responsibilities. This vision is consistent with the ways in which monetary and financial systems in Europe and at a global level are managed and evolve. Compare for example the quotation from Pozsar above, which describes the spontaneous creation by banks and financial institutions of a governance framework to manage a common pool good, short-term liquidity, filling a gap that had been left by the officially recognized mechanisms. We are witnessing a very large-scale experiment with the common European currency, about the outcome of which little is known but on which much depends.

43 Until the practically deserted auction of the German Bunds (only two-thirds sold) on 23 November 2011, many commentators spoke of the Bunds as risk-free assets. 
The different ways in which the United States and Europe have dealt with the crisis highlight the importance of a clear, well-defined and consolidated political structure. The US federal government has acted, through the Fed, within a very short time, making available as a first tranche $\$ 750$ billion in the Tarp scheme; other interventions aimed at generating a temporary but massive increase in liquidity followed. In Europe, on the contrary, all measures are of the too-little-too-late variety. The interventions arrive so late, after so many hesitations and are of such an insufficient size that instead of increasing the confidence of investors, entrepreneurs and consumers, they erode it even further. Had there been a structure with well-defined competences, like the US federal structure with its system of checks and balances, the destiny of the euro would have been less fluctuating and uncertain. ${ }^{44}$

\section{CONCLUSION}

Money is a common pool good at the decisive levels of interaction in monetary affairs. That is demonstrated by the fact that in the euro megaexperiment collective-action problems occupy a central position. As distinct from natural common pool resources, money is a cultural artefact (a social construction or an institution) that depends for its existence on the "theories" individuals hold. That complicates the problems of governance of the common pool good called money: a particular governance system is part and parcel of the good itself. A further complication derives from the fact that money is created and destroyed by a particular type of social amplifier, the money multiplier. The banking system is based on high levels of debt and leverage and acts as an amplifier of real and monetary shocks - a lesson we owe to Hayek. Together with the role of confidence and expectations, these factors make the monetary, financial and economic system highly sensitive to changes in the "general state of optimism". 45

The fact that trust, which is the (apparently renewable) resource that generates the flow of money, depends for its existence on the expectations

44 Tony Barber in the Financial Times of 26 November 2011 compares Swiss federalism, fiscal discipline and successful monetary policy with Europe's failure to solve the euro crisis. His conclusion is that it will be hard for Europe to follow the Swiss example, but that Europe might take over some of the Federation's solutions.

45 Cp. Reinhart \& Rogoff 2009, who speak of multiple equilibria: "For a given structure of debt and assuming all actors are pursuing their self-interest, there can be very different outcomes depending on expectations and confidence." (p. 60). 
and rules of behaviour, or culture, of the very same agents who are involved in the problems of collective action inherent to the management of monetary institutions and money brings an additional social amplification mechanism into play. When trust is high, it may produce effects that are exaggeratedly positive; in adverse times, a seemingly small diminution of trust may cause the state of confidence to collapse. In such a highly unstable environment, small causes may have big effects: the raising of eyebrows by a couple of political leaders may have decisive consequences.

As I have observed above, the solution of almost all crisis-related problems involves the attempt to turn a negative spiral into a positive one. This is much more difficult than the reverse, probably also for reasons that are rooted in human psychology (and which have been investigated by Kahnemann and Tversky). But there are also more "objective" reasons, too; for example, someone who has made investments for generating an income after his working life ends and sees their value diminish, faces an objective problem.

Some of the proposed solutions go in the direction of funds of temporary assistance. But such a proposal can only work if not all countries involved have difficulties of the same kind at the same time. For the original IMF this mechanism worked by definition because the sum of all trade deficits is identical to the sum of all trade surpluses. The same is not true for public deficits. On the contrary, a country that fails to refinance its debt risks contaminating others. This is another instance of a collective-action problem: there is a risk that if things go wrong for one country, things will go wrong for all countries. This is the danger the EFSF runs, particularly if it has the possibility of leverage. There must be the perspective that temporary aid to a country in need leads to an improvement of its economy in a relatively short time. The EFSF may ask for guarantees but these will never be enough; in the end, aid rests on trust. That also means that if the EFSF or any other institution or mechanism succeed in gaining the trust of governments, investors and citizens, the very fact that assistance is given may increase confidence in the country or institution that asks for it; it may even be the turning point in the negative spiral. ${ }^{46}$

Several of the proposed solutions to the euro crisis involve the activation or further reinforcement of procedures and institutions that require additional collective action. But there are no proposals for resolving that problem: the ECB must purchase sovereign bonds - but Germany, The Netherlands and Finland were opposed; the ESM must have the possibility to borrow reserves

46 It may, of course, also have the effect of stigmatizing the receiver of aid. The conditions under which one or the other effect produces itself deserve further analysis. 
with which it can operate like a bank - again the same countries are against; the proposal by three German "wise men" (Financial Times, 10 November 2011) for a jointly guaranteed fund for the repayment of 2.300 billion euro of public debt, etc. If these procedures or institutions were added to the existing ones, with their unsolved problems of governance, they would complicate the existing collective-action problems even further.

Perhaps the road ahead should be a different one and the agents involved would do better to solve the collective-action problems that arise with the existing mechanisms and institutions, or to reduce the number of institutions. What happens in reality seems to go in the opposite direction; when key agents fail to solve a collective-action problem arising from the use of an existing mechanism or institution, they propose to add another. As a consequence, agents, in their haste to save time, are wasting time instead. Investors take ever less time to learn that the next solution that is proposed is not effective. As a consequence, trust is ever more diluted. The lack of a clear decision structure makes itself felt more and more.

\section{Too big to fail, too big to save}

While at the level of relationships between individuals money is subtractable, at the level of the banking system there is almost an inversion: through the money multiplier, the money that I "subtract" from you and use to make payments inflates the money supply non-linearly (if the reserve percentage of all banks is $3 \%$, every additional euro that enters the system adds up to 33 euro to the money supply). If we rise to the level of the relationships between banks and governments, money becomes subtractable again: the government debts are so big that a sovereign bankruptcy risks bringing down the banks that hold them. Jim Millstein in the Financial Times of 15 November 2011 speaks of a "death spiral link of banks and government." So, rising upwards through various levels of interaction, money first has the characteristics of a common pool good, then assumes those of a public good, only to return to being a common pool good again.

Originally, the expression "too big to fail" was used for banks whose bankruptcy would have caused, because of the dimensions of their assets and their high connectedness, cumulative negative effects that would threaten the stability of the global monetary and financial system. Later the label was also applied to countries of the euro zone whose public debt is so substantial in absolute terms that their failure to pay back could cause such massive losses for holders of these debt titles that the stability of the euro and the EMU members' economies could be jeopardized. In the case of Greece it is thought that such losses would not affect stability substantially, but Italy is generally 
deemed to be beyond the danger line. On the other hand, the size of Italian public debt (about 2,000 billion euros) is such that no existing monetary institutions have the means to buy enough of it to give back confidence to investors. But if things are like this, the conclusion can only be that a country that is too big to fail and at the same time too big to save can only help itself.

The idea of certain European politicians that the crisis must be solved by the ECB and other monetary institutions is based on the tacit assumption that the crisis is a "technical" economic and financial problem. However, as the governor the German central bank Jens Weismann has said in an interview with the Financial Times of 14 November, the euro crisis needs a political solution. This idea is shared by US president Barack Obama, who said on 16 November 2011 that "the problem of the debt crisis is political, not technical" ${ }^{47}$ This is consistent with the fact that the problems surrounding the euro and the global monetary and financial system are very complex collective-action problems. In 1999 the common European currency was introduced (it became fully operative in 2002) as a club good. It evolved rapidly into a common pool good without there being an adequate governance system to keep the resource that the euro is a product of from being exhausted. Now it is the task of the very same political world that has created this common pool good to also create the institutional framework to save this source, which is trust.

Perhaps this is the main general lesson we can learn from Elinor Ostrom, and it also applies to the euro: the governance of a cultural common pool good such as money is not only a technical problem, but also, and to a greater extent, a political problem, which requires choice, trust and commitment.

\section{REFERENCES}

Athanassiou, P., 2009, "Withdrawal and expulsion from the EU and the EMU. Some reflections", European Central Bank Legal Working Papers Series

Birner, J., 1999, "Making markets", in Dow, S.C. \& Earl, P.E. eds., Economic Organisation and Economic Knowledge: Essays in Honour of Brian Loasby, Cheltenham, Edward Elgar

Birner, J., 2000, "Nascita e struttura del programma di ricerca economico di F.A. Hayek", in Clerici, G. \& Rizzello, S. eds., Organizzazione, informazione e

47 In early August 2012, the Governor of the ECB, Draghi, made it clear that the "technical" assistance of the ECB in buying government bonds in the secondary market would be conditional upon governments' taking the political responsibility for creating the conditions for improving the prospects of their national economies. A month later the programme was operational. 
conoscenza. Saggi su Hayek, volume I, Turin, UTET

Birner, J., 2002, "A conservative approach to progress in economics", in Boehm, S., Gehrke, C., Kurz, H. \& Sturm, R. eds., Is there progress in economics? Cheltenham, Edward Elgar

Birner, J., 2009, “F.A. Hayek's Monetary Nationalism after Seven Decades", paper presented at the $5^{\text {th }}$ annual conference of Storep, Florence

Birner, J., 2009a, "Social capital and value creation through innovation: what sociologists and economists can learn from each other and from the history of thought", paper presented at the $5^{\text {th }}$ annual conference of Storep, Florence

Birner, J. \& Ege, R., 1999, “Two Views on Social Stability: An Unsettled Question”, American Journal of Economics and Sociology

Boerio, Giuseppe, 1829, Dizionario del dialetto veneto, Venezia, Andrea Santini e figlio

Coase, R.H.m 1988, The Firm, the Market and the Law, Chicago, University of Chicago Press

Draghi, M., 1999, "Strengthening Financial Systems", in Brooks, D.H. \& Queisser, M. eds., Financial Liberalisation in Asia, Paris, OECD/Asian Development Bank

Draghi, M., 2011, "Considerazioni finali", 31 maggio 2011, Rome, Banca d'Italia

Dragis Aligica, P. \& Boettke, P.J., 2009, Challenging Institutional Analysis and Development. The Bloomington School, Milton Park, Routledge

Hayek, F.A., 1937, Monetary Nationalism and International Stability, Augustus M. Kelley $\left(1^{\text {st }}\right.$ ed. 1937, London, Longmans Green

Hayek, F.A., 1942, The Pure Theory of Capital, London, Routledge \& Kegan Paul

Ingham, G., 2004, The Nature of Money, Cambridge, Polity Press

Katzensteiner,T. - Papendick, U., 2011, "Kasino fatal", Manager Magazin Vol. 4, pp. 31-38

Mahoney, J., Carleton Asher, C. - Mahoney, J., 2004, "Towards a Property Rights Foundation for a Stakeholder Theory of the Firm", New York, Federal reserve bank of New York, research paper

Möllering, G., 2006, Trust: Reason, Routine, Reflexivity, Amsterdam, Elsevier

Niehans, J., 1971, "Money and Barter in General Equilibrium with Transaction Costs", American Economic Review Vol. 61, n. 5, pp. 773-783

Ostrom, E., 1990, Governing the Commons: The Evolution of Institutions for Collective Action, Cambridge, Cambridge University Press

Ostrom, E., 2003, "How types of goods and property rights jointly affect collective action", Journal of Theoretical Politics Vol. 15 n. 3, pp. 239-270

Ostrom, E., 2010, "Analyzing collective action", International Association of Agricultural Economists, pp. 155-166

Ostrom, E. - Hess, C., 2007, "Private and Common Property Rights", Library Publications, Paper 24, Syracuse University, http://surface.syr.edu/sul/24, last accessed 31 October 2012

Popescu, A., 2009, "Money as a Global Public Good", Annals of Faculty of Economics, Timisoara, vol. 2, issue 1, pp. 517-521

Poteete, A.R., Janssen, M.A. - Ostrom, E., 2010, Working together. Collective Action, 
the Commons, and Multiple Methods in Practice, Princeton, Princeton University Press

Pozsar, Z., 2011, "Institutional Cash Pools and the Triffin Dilemma of the US Banking System", Washington, IMF working paper 11/190

Reinhart, C.M. \& Rogoff, K.S., 2009, This Time is Different, Princeton, Princeton University Press

Samuelson, P.A. \& Nordhaus, W., 2009, Economics, 19 ${ }^{\text {th }}$ ed., New York, McGrawHill

Samson, M., 2007, "Privatizing collective public goods: a case study of street cleaning in Johannesburg, South Africa", Studies in Political Economy Vol. 79, pp. 119143

Simmel, G., 1989 [1900], Philosophie des Geldes, Berlin, Suhrkamp

Szász, A., 1999, The Road to European Monetary Union, London, MacMillan

Tett, G., 2009, Fool's Gold. How the bold dream of a small tribe at J.P. Morgan was corrupted by Wall Street greed and unleashed a catastrophe, New York, Free Press

Yamagishi, T. - K. S. Cook, 1993, "Generalized exchange and social dilemmas." Social Psychology Quarterly 56(4), pp. 235-248 